\title{
COMUNICACÃO
}

\section{Influência da temperatura e do fotoperíodo na germinação in vitro de escleródios de Sclerotium cepivorum, agente causal da podridão branca do alho e da cebola}

\author{
Leandro Luiz Marcuzzo ${ }^{1}$, Leonardo Luiz ${ }^{1}$
}

${ }^{1}$ Instituto Federal Catarinense - IFC/Campus Rio do Sul, CP 441, 89.163-356, Rio do Sul, SC

Autor para correspondência: Leandro Luiz Marcuzzo (leandro.marcuzzo@ifc.edu.br)

Data de chegada: 11/04/2017. Aceito para publicação em: 02/05/2017.

$10.1590 / 0100-5405 / 178073$

Sclerotium cepivorum (Berkeley) é o agente causal da podridão branca do alho (Allium sativum L.) e da cebola (Allium cepa L.). A doença ocorre em algumas áreas produtoras do sul e sudeste do Brasil, causando grandes perdas em lavouras onde se encontra o patógeno (Reis \& Oliveira, Identificação e manejo da podridão-branca do alho e da cebola. Brasília: Embrapa hortaliças, comunicado técnico 91, 6 p. 2013). Os sintomas da doença são observados na parte aérea dessas culturas causando subdesenvolvimento, amarelecimento, morte das folhas mais velhas e a podridão dos bulbos. Em ambiente úmido, os bulbos e a região do caule próximo ao solo ficam recobertos por abundante micélio branco onde são produzidas de forma aglomerada estruturas de resistência conhecidas como escleródios e de coloração preta. Pesquisas relacionadas à podridão branca do alho e cebola no Brasil ainda são escassas. Para tanto, o conhecimento da biologia do patógeno é de grande importância para compreender o desenvolvimento da doença no campo e o seu manejo. Diante disso, este trabalho teve como objetivo avaliar em condições in vitro a influência da temperatura e do fotoperíodo na germinação de escleródios de $S$. cepivorum. O trabalho foi realizado no Laboratório de Microbiologia e Fitopatologia do Instituto Federal Catarinense - IFC/Campus Rio do Sul e o experimento foi conduzido em delineamento inteiramente casualizado com cinco repetições em cada tratamento. O inóculo de $S$. cepivorum foi obtido do isolamento de escleródios obtidos de plantas de alho em placas de Petri contendo meio de cultura BDA (Batata-Dextrose-Ágar) e preservado em geladeira $\left( \pm 4^{\circ} \mathrm{C}\right)$. Discos do inóculo com $9 \mathrm{~mm}$ de diâmetro foram removidos dessas placas e inoculados no centro de placas de Petri contendo uma fina camada de meio de cultura BDA e incubados à $20^{\circ} \mathrm{C}$ e fotoperíodo de 12 horas durante 15 dias para produção dos escleródios. Após isso, dez escleródios foram coletados e distribuídos equidistantes em cada placa de Petri contendo BDA com composto de suco de escama de cebola a $10 \%$ para favorecer a germinação dos escleródios e em seguidas e incubados em câmera de germinação do tipo B.O.D. (Demanda Biológica de Oxigênio) nas temperaturas de 10, 15, 20,25 , e $30^{\circ} \mathrm{C}\left( \pm 1^{\circ} \mathrm{C}\right)$ e fotoperíodo de 12 horas luz. Diariamente era feito a contagem dos escleródios germinados em cada tratamento, até que um deles apresentasse a germinação de todos os escleródios. Isto ocorreu aos seis dias nas placas incubadas na temperatura de $20^{\circ} \mathrm{C}$. A partir da obtenção da temperatura ótima de desenvolvimento, repetiu-se o ensaio seguindo a mesma metodologia acima, incubando-se a $19^{\circ} \mathrm{C}$ com fotoperíodos de $0,6,12,18$ e 24 horas, a fim de avaliar o fotoperíodo favorável a germinação dos escleródios. Verificou-se que a temperatura influenciou na germinação dos escleródios, tendo apresentado melhor desenvolvimento entre as temperaturas de 15 e $20^{\circ} \mathrm{C}$ (Figura 1A), onde germinaram em média de 96 e 100\% dos escleródios respectivamente. Utilizando a equação gerada pela curva $\left(y=-0,925 x^{2}+35,66 x-235,2\right.$; $\mathrm{R}^{2}=0,984$ ) (Figura $1 \mathrm{~A}$ ) obtém-se a temperatura ideal de $19^{\circ} \mathrm{C}$ para a germinação de escleródios de $S$. cepivorum. A temperatura da germinação de escleródio no presente trabalho é acima dos $16^{\circ} \mathrm{C}$ utlizada no trabalho de Rezende \& Zambolim (Fitopatologia brasileira, v.11, n.11, p.493-500, 1986) para a germinação de escleródios de S. cepivorum provenientes do solo. Em relação a formação de escleródios em diferentes fotoperíodos observou-se a formação de uma linha polinomial (Figura 1B), que através da equação $y=-0,015 \mathrm{x}^{2}-0,152 \mathrm{x}+98,05\left(\mathrm{R}^{2}=0,522\right)$, verificou-se que o fotoperíodo mais favorável ao desenvolvimento é de zero horas de luz com $100 \%$ dos escleródios germinados quando comparado com 24 horas de luz que obteve apenas $82 \%$, porém pouco expressiva a diferença do fotoperíodo ao se comparar com a temperatura. As informações obtidas em relação à temperatura e o fotoperíodo na germinação de escleródios de $S$. cepivorum permitem um maior conhecimento da biologia do agente causal da podridão branca do alho e da cebola, auxiliando no entendimento da epidemiologia e suporte para manejo da doença no campo.
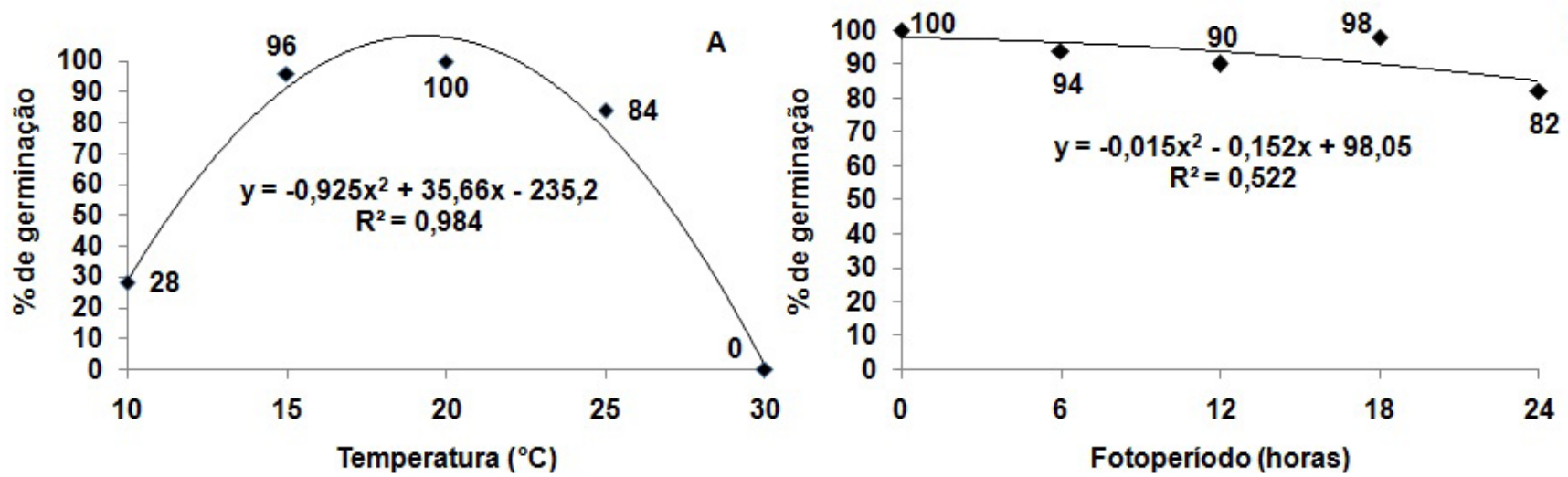

Figura 1. Curva de germinação de escleródios in vitro de Sclerotium cepivorum em diferentes temperaturas (A) e fotoperíodos (B). IFC/Campus Rio do Sul, 2017. 